\title{
Vermicompost and Mycorrhizae Use on Cedrela odorata L. Growth in Nursery Conditions
}

\author{
Castillo-Aguilar, Crescencio de la Cruz ${ }^{1}$; Ferrera-Cerrato, Ronald ${ }^{2}$; Chiquini-Medina, Ricardo Antonio ${ }^{3}$; \\ Chable-Chan, Carlet Osmar ${ }^{1+}$; Dzib-Castillo, Benito Bernardo ${ }^{3 *}$ \\ ${ }^{1}$ Colegio de Postgraduados, Campus Campeche, México. ${ }^{2}$ Colegio de Postgraduados, Campus \\ Montecillo, México. ${ }^{3}$ Tecnológico Nacional de México/Instituto Tecnológico de Chiná, Campeche, \\ México
}

*Corresponding author: bernadzib ayahoo.es

\begin{abstract}
Objective: To evaluate the effect of mycorrhizal inoculation and the use of vermicompost on the growth of red cedar (Cedrela odorata L.) seedlings under nursery conditions.
\end{abstract}

Materials and Methods: The treatments were with and without a Glomus intraradices inoculum, combined with different amounts of vermicompost in the growth substrate (0,10,20 and 30\%), in a completely randomized block design. The variables evaluated were plant height $(\mathrm{PH})$, stem diameter (SD), number of leaves (NL), dry weight (DW), mycorrhizal colonization (MC) and number of spores (NS).

Results: The addition of vermicompost to the growth substrate improved the growth of $C$. odorata seedlings, the best treatment being $30 \%$ of vermicompost without mycorrhizae. The percentage of mycorrhizal colonization and number of spores per $100 \mathrm{~g}$ of soil decreased when increasing the amount of vermicompost in the substrate.

Study Limitations/Implications: None.

Findings/Conclusions: Vermicompost was the leading promoter of $C$. odorata plant growth under nursery conditions.

Keywords: substrate, arbuscular mycorrhizal fungi, colonization.

\section{INTRODUCTION}

\section{T}

he quality of the substrate used in nurseries is one of the factors that influence the growth of plants, which means it is important to have organic and microbiological alternatives for the sustainable production of Cedrela odorata plants (Oros-Ortega et al., 2015). Vermicompost is characterized by being made up of finely divided, highly porous, aerated, drainable, moisture retaining materials. These materials have reduced quantities of soluble salts, higher cation exchange capacity (CEC) and a growing number of total humic acids. It is an organic substrate with high content of nitrogen, potassium, phosphorus, magnesium and micronutrients (Ruíz, 2011); it contains biologically active substances that regulate vegetative growth (Atiyeh et al., 2000c). 
In addition, vermicompost has a large surface area, which permits it to adsorb and strongly retain the nutritional elements, which are easily assimilable by plants (Atiyeh et al., 2000a; Atiyeh et al., 2000c), besides having a high capacity to be mixed with the soil in order to slowly liberate nutritional elements and accelerate plant growth (Capistran et al., 1999).

Another important biological element to be taken into account in the substrate is the use of arbuscular mycorrhizal fungi (AMF) which has become a viable alternative in order to reduce losses in multiplication, acclimatization and adaptation processes of different plant species in diverse agro ecological conditions.

Due to the low quality of $C$. odorata seedlings grown in nurseries, the use of AMF has been proposed, which may improve development and growth of seedlings during their first months of life, considering that some species of the Cedrela genus can potentially form mycorrhizae with Glomus and Acualospora genera (Souza et al., 2006). The symbiosis between arbuscular mycorrhizal fungi and plants plays an important role in the adaptation of plants in terrestrial ecosystems (Honrubia, 2009). One of the benefits of this symbiosis is related to plant nutrition in environments with nutrient restrictions, where the plant supplies carbohydrates to the fungi for its metabolism and the fungus aids in intake and transport of the nutrients the plant requires (Smith, 2013). The symbiosis favors the plant's tolerance to biotic and abiotic stress, improves the physical characteristics of the soil, and favors the diversification of plant species in ecosystems (Smith and Read, 2008).

C. odorata seedlings with high mycorrhizal colonization have been obtained when the seedlings were inoculated with spores native to high evergreen and medium subevergreen forests (Méndez-Cortés et al., 2013). A positive effect has also been observed with the inoculation of Glomus spp. in terms of plant height, stem diameter and number of leaves 30,60 and 90 days after sowing in Antillean mahogany (Swietenia micorrmahagoni (L.) Jaca.) in nurseries (Bango-Folgoso et al., 2013).

Similar results were found for plant height, stem diameter and number of leaves by Falcon-Oconor et al. (2013) in Swietenia mahagoni and Lisyloma latisiliquum inoculated with Glomus hoi like and Glomus intraradices. When Oros-Ortega et al. (2015) evaluated C. odorata seedlings inoculated with Rhizophagus intraradices in nurseries, they found larger and more vigorous plants in terms of plant height, stem diameter, root dry weight, plant dry weight, and mycorrhizal colonization of up to $50 \%$.

Similar results were found by Méndez-Cortés et al. (2013) in C. odorata, obtaining greater height, diameter, number of folioles, aerial and radicular dry biomass, number of spores and colonization percentage (50 to $80 \%)$. These results make sense with that cited by MoinaQuimi et al. (2018) who determined that the percentage of colonization of tropical fungi species is higher than $50 \%$.

Accordingly, and in the interest of generating knowledge about the use of vermicompost and the application of mycorrhizal fungi, the effect of vermicompost and mycorrhization of the roots of $C$. odorata on the growth of seedlings under nursery conditions, was evaluated.

\section{MATERIALS AND METHODS}

The study was carried out in nurseries in Campeche, Mexico. The predominant climate is warm humid, with summer rains (Awo) according to the Köppen climate classification modified by García (2004), with an average annual precipitation of $1290 \mathrm{~mm}$ and mean temperature of $22^{\circ} \mathrm{C}$.

For this study C. odorata seeds were used which were obtained from fruits collected from trees in Campeche communities, making sure to use intact unopened capsules without any insect or fungal damage. The fruits (capsule) were dried by solar dehydration for $8 \mathrm{~h}$ during $4 \mathrm{~d}$, afterwards they were disinfected with 5\% sodium hypochlorite during $7 \mathrm{~min}$. Then they were rinsed with sterile water and stored in glass jars in a dry and cool place. In order to obtain seedlings, seeds were germinated in plastic trays with 72 cavities previously washed and sterilized, using Peat-Moss ${ }^{\circledR}$ as substrate, placing one seed per cavity at a depth of $2 \mathrm{~cm}$. Once the seedlings had been in the trays for 95 days after sowing (DAS), they were transplanted to black polyethylene bags with $2.1 \mathrm{~kg}$ capacity using sterilized black forest soil with methyl bromide as substrate. The vermicompost used as part of the study's treatment was sterilized with a 100 mg dose of Basamid ${ }^{\circledR}$ on a surface of $1 \mathrm{~m}^{2}$ per $30 \mathrm{~cm}$ of depth; afterwards it was covered with polyethylene plastic during seven days, and then aerated for three days. When the seedlings were transplanted, they were inoculated with the mycorrhizal fungus Glomus intraradices at a rate of $10 \mathrm{~g}$ per plant. The colonization percentages of 
roots used as inoculum for $G$. intrarradices were $90 \%$ colonization with 1200 spores per $100 \mathrm{~g}$ of soil. The experimental design was a randomized block design with eight treatments and 40 repetitions per treatment, considering one plant per bag as an experimental unit. The treatments were 0-0, 10$0,20-0,30-0,0-M, 10-M, 20-0$ and 30-0, considering the first number as the percentage of vermicompost in the substrate and the second as the inoculation with arbuscular mycorrhizal fungi (AMF) G. intrarradices.

The experimental unit consisted of 40 plants lined up at a distance of 1.5 $\mathrm{m}$ between lines and $40 \mathrm{~cm}$ between plants. The study variables were plant height (PH), stem diameter (SD), number of leaves (NL), leaf area (LA), mycorrhizal colonization (MC), and number of spores (NS). Measurements were taken every $30 \mathrm{~d}$, with a total of five measurements. The quantification of dry weight was calculated by placing leaves, stems and roots into brown paper bags which were then dried in an oven at $80{ }^{\circ} \mathrm{C}$ during 48 hours. In order to determine the presence of the mycorrhizal fungus and to quantify colonization, a technique was used to color the fungal structures in the root and then to count the infection by observing through a microscope using the Phillips and Hayman method (1970). The infection percentage was determined based on the total segments colonized by the fungus and the segments that had arbuscules and vesicles, depending on the case. The infection percentage was calculated using the following equation:

$$
\text { \%infection }=\frac{\text { No. of colonized segments }}{\text { No. of observed segments }} \times 100
$$

Separating and counting spores was carried out using the Nicolson (1963) method, mentioned by Ferrera-Cerrato and Gonzáles-Chávez (1993) as a sieving and decanting method, which requires the observation and evaluation of spores through a stereoscopic microscope or, sometimes, an optic microscope. The number of spores was obtained by counting the amount found on filter paper with the use of a stereoscopic microscope. The result was expressed in number of spores per $100 \mathrm{~g}$ of dry soil using the following formula:

Spores in $100 \mathrm{~g}$ of dry soil $=\frac{\text { (No. of counted spores) }(\text { grams of dry soil) }}{100 \mathrm{~g} \text { humid soil }}(100)$

The data obtained was subjected to a variance analysis and Tukey's multiple comparison of means test (Tukey, $\alpha=0.05$ ) using the statistics program SAS (Statistical Analysis System Institute, 2004).

\section{RESULTS AND DISCUSSION}

\section{Plant Height and Stem Diameter}

The results showed a greater effect with vermicompost in substrate than those inoculated with AMF. At a higher concentration of vermicompost in the substrate, the plant's height and diameter were greater, showing significant differences between treatments during the dates of measurement (Table 1).
The greatest height $(28.65 \mathrm{~cm})$ was obtained at 150 days after transplant (DAT) using the substrate with 30\% vermicompost without AMF inoculation, while the best inoculation treatment was with AMF and $10 \%$ vermicompost $(22.61 \mathrm{~cm})$. These results indicate the feasibility of the use of vermicompost in the production of nursery seedlings which contribute to the development of $C$. odorata plants.

The effect of the AMF was not observed in the growth of the seedlings due to the substrate enriched with vermicompost, which made nutritional elements available through this organic component, as is the case with phosphorus that reduces the capacity of AMF for the extraction and transport of available chemical elements to the plant. With respect to mycorrhizal inoculation the results are not in accordance with what was found in previous studies carried out with c. odorata where mycorrhizal inoculation favored an increase in plants' height and diameter (FalconOmar et al., 2013; Bango-Folgoso et al., 2013; Oros-Ortega et al., 2015). However, the results obtained by Moreno-Reséndez et al. (2014) with Acacia pennatula (Schltdl. and Cham.) Benth. determined that the use of $10 \%$ vermicompost and $90 \%$ natural soil obtained the best results at 240 days after transplant (DAT). It is also important to consider that the results obtained could be due to factors such as the type of mycorrhizal fungus, the amount of inoculum, the organic material content in the substrate, as well as the plant species being studied.

In terms of the number of leaves, the results showed a similar trend to those observed for height and 
Table 1. Height and diameter stem per plant average of Cedrela odorata with different levels of vermicompost and mycorrhizal fung

Treatment

Height plant (cm)

Stem diameter $(\mathrm{cm})$

Days after

90

150

60

150

\begin{tabular}{c|c|c|l|l}
\hline 00 & $9.96 c$ & $10.71 f$ & $0.70 c$ & $1.08 d$ \\
\hline $10-0$ & $12.40 b$ & $18.98 d$ & $0.77 a b c$ & $1.18 c$ \\
\hline $20-0$ & $13.46 a$ & $25.51 b$ & $0.92 a b$ & $1.25 b$ \\
\hline $30-0$ & $13.98 a$ & $28.65 a$ & $0.94 a$ & $1.30 a$ \\
\hline $0 M$ & $13.43 a$ & $14.52 a$ & $0.75 a b c$ & $1.24 b$ \\
\hline $10 M$ & $12.18 b$ & $22.61 c$ & $0.74 a b c$ & $1.31 a$ \\
\hline $20 M$ & $10.61 c$ & $11.93 f$ & $0.71 c$ & $1.09 d$ \\
\hline $30 M$ & $10.61 c$ & $11.65 f$ & $0.73 b c$ & $1.09 d$ \\
\hline$M S D$ & 0.73 & 1.30 & 0.20 & 0.03
\end{tabular}

Treatments with the same letter are statistically the same (Tukey, 0.05). $M S D=$ Minimum significant difference. Results of two samplings of the five carried out

stem diameter, where the higher number of leaves was due to the use of vermicompost in the substrate and not because of mycorrhizal inoculation (Figure 1).

The effect of vermicompost on the growth of C. odorata plants was attributed to higher availability of nutrients in the substrate, the improvement of its physical properties, and higher moisture availability (Costa and Martin, 2018). A higher number of leaves was observed with the 30V-M treatment (66.75 leaves), and a similar trend was found with the 10V-M treatment (56.57 leaves).

The number of leaves obtained (66.07) at $90 \mathrm{~d}$ with Glomus intraradices inoculation without the use of vermicompost is similar to that found by BangoFolgoso et al. (2013) in mahogany plants (Swietenia mahagoni) who obtained 9.03 leaves on average per plant with an inoculation with the Glomus genus. On the other hand, Méndez-Cortés et al. (2013) found that during the initial development of C. odorata there were plants with a higher number of leaves using different sources of mycorrhizal inoculum, with the results varying depending on the type of soil and the relation with the organic matter present.

The dry weight increased with 30\% vermicompost application without AMF inoculation, with each section of the plants weighing $4.26 \mathrm{~g}$ (leaves), $10.94 \mathrm{~g}$ (stem) and $14.93 \mathrm{~g}$ (roots). In terms of the mycorrhizal inoculation treatments, OV-M and 10V$M$ were the most noteworthy. All of the treatments with vermicompost with or without mycorrhizal inoculation exceeded the control treatment in terms of weight of leaves, stem and root.

The results suggest that the addition of vermicompost improved the availability of nutrients and improved the physical properties of the substrate, which could be interpreted as improved photosynthesis activity in the plant. This confirms an overall improved plant quality for future establishment in the field, which agrees to that established by Costa and Martín (2018). Although the mycorrhizal effect was overshadowed by the use of vermicompost, it is important to consider its subsequent effect for the survival of $C$. odorata plants when they are taken into the field where agro-climatic conditions could be more limited. In the field it is important to evaluate the relationship of foliage weight and dry root weight, in which the best treatments were those inoculated with $G$. intraradices based on the results in Table 2 . Those in the nursery business prefer plants that are not too big and with abundant roots; roots with sufficient anchoring capacity, but especially the capacity to explore and aid in the extraction of the field's nutrients.

\section{Mycorrhizal Colonization and Number of Spores}

The percentage of mycorrhizal colonization (56.6\%) and the number of spores per $100 \mathrm{~g}$ of soil (51.40) were higher without vermicompost in the substrate, and decreased as the amount of organic component increased (Figure 2) to values of $50.8 \% 42.8 \%, 32.2 \%$ for 10,20 and $30 \%$ of vermicompost, respectively. A similar trend was seen with the number of spores per $100 \mathrm{~g}$ of soil with values

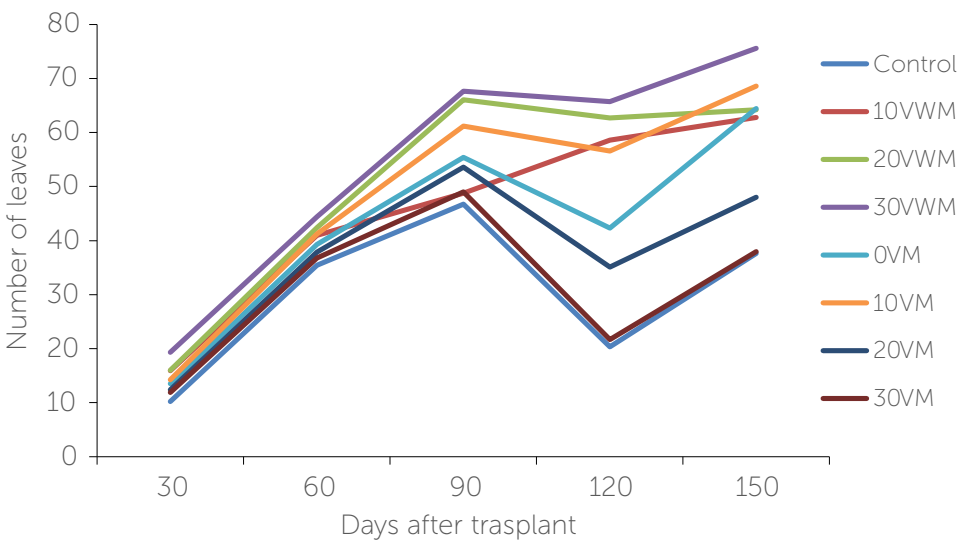

Figure 1. Growth kinetics average per plant of Cedrella odorata by vermicompost and mycorrhizal inoculation use (Glomus intraradices). 10VWM: $10 \mathrm{~g}$ of vermicompost without mycorrhiza, 20VWM: $20 \mathrm{~g}$ of vermicompost without mycorrhiza, 30VWM: $30 \mathrm{~g}$ of vermicompost without mycorrhiza, OVM: $0 \mathrm{~g}$ of vermicompost with mycorrhiza, 10VM: $10 \mathrm{~g}$ of vermicompost with mycorrhiza, 20VM: $20 \mathrm{~g}$ of vermicompost with mycorrhiza, 30VM: $30 \mathrm{~g}$ of vermicompost with mycorrhiza. 
Table 2. Dry weight average of leaves, stem, and root average of Cedrela odorata plants growing at different levels of vermicompost and inoculation with Glomus intraradices as substrate.

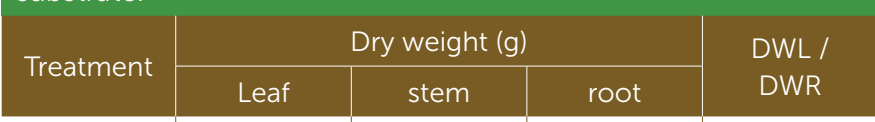

\begin{tabular}{c|c|c|c|c}
\hline 00 & $0.81 c$ & $3.69 c$ & $4.50 d$ & 1.00 \\
\hline $10-0$ & $1.56 b c$ & $7.61 b c$ & $7.61 b c d$ & 1.20 \\
\hline $20-0$ & $3.07 a b$ & $10.04 a b$ & $10.95 a$ & 1.20 \\
\hline $30-0$ & $4.26 a$ & $10.94 a b$ & $14.93 a$ & 1.02 \\
\hline $0 M$ & $1.88 b c$ & $12.73 a$ & $10.05 a b$ & 1.45 \\
\hline $10 M$ & $2.80 a b c$ & $10.85 a b$ & $14.04 a$ & 0.97 \\
\hline $20 M$ & $1.24 b c$ & $5.25 c$ & $9.13 b c$ & 0.71 \\
\hline $30 M$ & $0.82 c$ & $4.01 c$ & $5.68 c d$ & 0.85 \\
\hline MSD & 2.14 & 3.98 & 3.50 & \\
\hline
\end{tabular}

Treatments with the same letter are statistically the same (Tukey, 0.05). MSD = Minimum significant difference.

at $44.20,39.40$ and 29.60 spores per $100 \mathrm{~g}$ of soil. The results are attributed to the enriched organic substrate which reduced the functionality of the AMF.

The value found for mycorrhizal colonization without the use of vermicompost was $55.60 \%$, within the values found by Oros-Ortega et al. (2015) at 50\%, MoínaQuimí et al. (2018) at 50\%, and Méndez-Cortés et al. (2013) from 50 to 80\%. Authors such as Oros-Ortega et al. (2015), when working with red cedar, found that inoculation produced high levels of mycorrhization in roots by the sixth month. Moreno-Resendez et al. (2014) considered that timely inoculation occurs in the early stages of plant growth and increases as new roots are formed. The number of spores found was good compared to those reported on mahogany grown in nurseries by Guuetra-González (2009) at 12 for Caulospora spp., 3 for Glomus spp., and 6 for Entropospora spp.

In their study using native mycorrhizal fungal species, Mendes-Cortez et al. (2013) found an average number of 30.38 spores per $100 \mathrm{~g}$ of soil, amount lower than that found in the present study with Glomus spp. of $51.40100 \mathrm{~g}^{-1}$ of soil.

\section{CONCLUSIONS}

The use of organic fertilizers could be a sustainable alternative for the production of red cedar (C. odorata) in nurseries. The use of vermicompost at a $30 \%$ dose as part of the substrate promoted a more vigorous growth in the plants. The effect of biofertilizer with arbuscular mycorrhizal fungi (Glomus intraradices) favored better root development, which is a favorable effect in field conditions.

\section{REFERENCES}

Atiyeh, R. M. Subler, S., Edwards, C. A., Bachman, G., Metzger, J. D. \& Shuster, W. (2000a). Effects of vermicomposts and composts on plant growth in horticultural container media and soil. Pedobiologia. 44: 579-590.

Atiyeh, R. M., Arancon, N., Edwards, C. A. \& Metzger, J. D. (2000c) Influence of earthworm-processed pig manure on the growth and yield of greenhouse tomatoes. Biores. Technol., 75: 175180.

Bango-Folgoso JC, L Pérez Velázquez \& Torres-Martínez L. (2013). Alternativas biológicas para la obtención de posturas de caoba antillana en la etapa de vivero. Vol 16 no 16 pag 1-110.

Capistran, F., E. Aranda \& Romero, J. C. (1999). Manual de Reciclaje, Compostaje y Lombricompostaje. Instituto de Ecología, A.C. Xalapa, Ver., México. 150 p.

Falcon-Oconor E, M C Rivera Nelson y Rodríguez-Leyva O. 2013. Efecto de la inoculación de hongos micorrozógenos sobre la producción de posturas forestales en diferentes tipos de suelos. Cultivos tropicales 34 (3): 32-33

Honrubia, M. (2009). Las micorrizas: una relación planta-hongo que dura más de 400 millones de años. Anales del Jardín Botánico de Madrid, 66(1), p. 133-14

Méndez-Cortés H., Marmolejo-Monsivais, J. G., Cantú - Sayalas, C. Olalde-Portugal, V., Estrada-Casrtillón, E., \& Posadas-Leal C. (2013). Respuesta de Cedrela odorata a diversos inoculantes micorrízicos procedentes de dos ecosistemas tropicales. Madera y Bosques 19(3):23-34

Moína-Quimi, E., Oviedo-Anchudia, R., Nieto-Barciona, S., HerreraSamaniegoj, P., \& Barcos-Arias, M. (2018). Evaluación de los hongos micorrízicos arbusculares en las zonas del trópico húmedo del Ecuador. Revista en línea http//www.revista biometría.com :3(1)532-537.

Moreno-Reséndez A., Solís-Morales, G., Blanco-Contreras, E., VázquezArrollo, J., Guzmán-Cedillo, L. M. P., Rodríguez-Dimas, N. \& Figueroa-Viramontes U. (2014). Desarrollo de plantas de
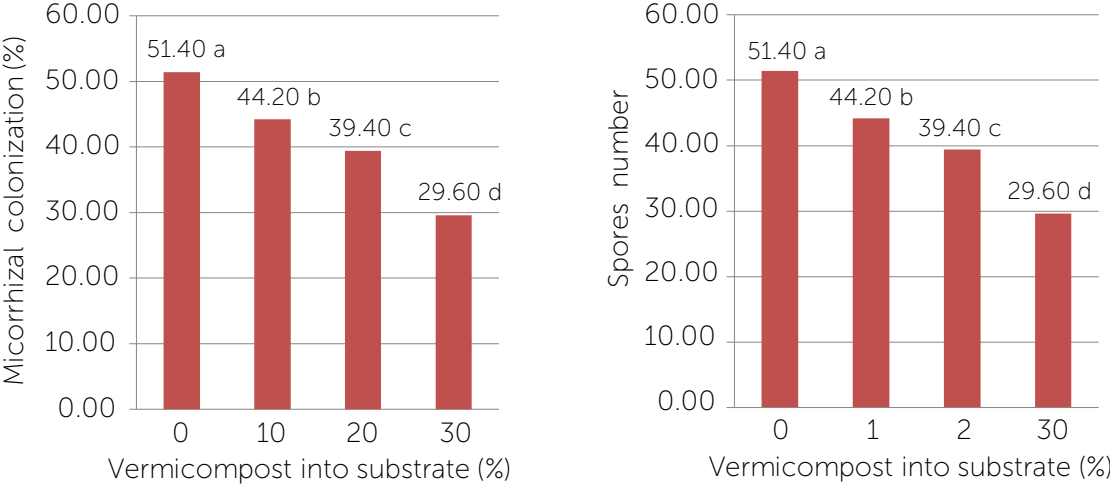

Vermicompost into substrate (\%)

Figure 2. Mycorrhizal colonization (left) and number of spores (right) percentage at different levels of vermicompost into the growth substrate. 
huizache (Acacia farnesiana) en Sustratos con Vermicomposta. Revista Chapingo, Serie Ciencias Forestales y del Ambiente 20(1):55-62.

Oros-Ortega, I., Alonso-López, A., Pérez-Moreno J., López-Collado, J. C., Lara-Pérez, L. A., Martínez-Garza, S. E., Solís-Ramos, L. Y. \& Andrade-Torres, A. (2015). Respuesta de plántulas de Cedrela odorata a la inoculación con Rhizophagus intraradices y diferentes niveles de defoliación. Revista Mexicana de Ciencias Agrícolas Vol.6 Núm. 301 de abril - 15 de mayo, 2015 p. 627-635

Phillips, J. M., \& Hayman, D.S. (1970). Improved procedures for cleaning roots and staining parasitic and vesicular arbuscular mycorrhizal fungi for rapid assessment of infection. Transactions of the British Mycological Society. 55: 158-162.

Ruíz, M. M. (2011). Taller de elaboración de lombricomposta: porque tener lombrices nos beneficia a todos. Universidad Iberoamericana. México, D.F., México. 23 p.

SAS Institute Inc. (2004). SAS/STAT User's guide, Version 9.1. SAS Institute. Cary, NC.

Smith, S.E. and Smith, A.F. (2011). Roles of Arbuscular Mycorrhizas in Plant Nutrition and Growth: New Paradigms from Cellular to Ecosystem Scales. Annual Review of Plant Biology, 62: 227-250.

Smith, S. D. \& Read, D. J. (2008). Mycorrhizal Symbiosis. 3 ed. New York (USA) London (UK): Academic, $787 \mathrm{p}$.

Souza, O. F., Saggin J. O. J., Ribeiro da Silva, E. M. \& Luís de Lima, E. W. (2006). Dependencia e resposta de mudas de cedro a fungos micorrizicos arbusculares. Pesq. Agropec. Bras. 41(1): 77-84 